\title{
Comparing public support for wildlife protection and climate protection
}

\author{
Tomáš Chabada, Jan Krajhanzl
}

Envigogika 16 (2) - Reviewed articles/Recenzované články/

Published/ Publikováno 5. 11. 2021

DOI: $10.14712 / 18023061.624$

\begin{abstract}
The main goal of our study is to compare attitudes to climate protection and wildlife protection, as the gap in this field of research - not only in the Czech Republic - persists. In this study we provide a detailed analysis and comparison of the public support for climate protection and wildlife protection using nationally representative data from the Czech Republic. The results of regression analyses have shown that support for both protections is significantly increasing with growing pro-environmental beliefs of people, leisure time they spent in nature and their altruism. Support for climate protection also rises with higher election participation, left-wing political orientation and younger age. Support for wildlife protection increases with growing trust in non-profit organizations while decreases with growing trust in science $\&$ research institutions. The comparison of groups defined according to their consent with climate protection and wildlife protection showed that support for wildlife protection can be characterized as a more inclusive environmental attitude than support for climate protection. The paper discusses the implications of these findings for protagonists of environmental politics and ways how they approach the public.
\end{abstract}

\section{Keywords}

Public support for climate protection; Public support for wildlife protection; Portrait Value Questionnaire; New Ecological Paradigm; Representative survey; Czech Republic

\begin{abstract}
Abstrakt
Hlavním cílem této studie je srovnat postoje veřejnosti $k$ ochraně klimatu a ochraně přírody, nebot $v$ této oblasti výzkumu existuje - nejen v České republice - stále výzkumné bílé místo. $V$ této studii přinášíme podrobnou analýzu a srovnání podpory reprezentativního vzorku české veřejnosti $\mathrm{k}$ ochraně klimatu a ochraně divoké přírody. Výsledky regresních analýz ukázaly, že podpora $v$ obou oblastech významně roste s rostoucím proenvironmentálním přesvědčením, volným časem tráveným v prírodě a altruismem. Podpora ochrany klimatu u respondentů také roste společně s vyšší volební účastí, levicovou politickou orientací a nižším věkem. Podpora ochrany prírody roste $s$ vyšší důvěrou v neziskové organizace, a na druhé straně klesá $s$ rostoucí důvěrou ve vědecké a výzkumné instituce. Srovnání skupin vymezených podle míry jejich souhlasu s ochranou klimatu a ochranou divoké prírody ukázalo, že podporu ochrany divoké př́rody Ize charakterizovat jako inkluzivnější environmentální postoj než podporu ochrany klimatu. Článek diskutuje důsledky těchto zjištění pro tvorbu environmentálních politik a způsoby práce $s$ veřejností $v$ této oblasti.
\end{abstract}

\section{Klíčová slova}

Veřejná podpora ochrany klimatu; Veřejná podpora ochrany divoké př́rody; Portrait Value Questionnaire; Nové ekologické paradigma, Reprezentativní šetření; Česká republika. 


\section{Introduction}

Within the field of study of environmental politics, the relation between public opinion and public policies has been discussed by a number of authors (e.g. Dunlap 1995, Burstein 2003, Weaver 2008, Shum 2009, Pietsch and McAllister 2010, Daniels et al. 2013). Although this relation need not always be entirely unambiguous, a majority of authors emphasize the two areas are interconnected to a certain extent (e.g. Dunlap 1995, Burstein 2003, Weaver 2008, Daniels et al. 2013). Inquiries into values, beliefs and behaviours of citizens provide policy makers with important information regarding public support for the policies they propose. Support of public opinion may be of key importance not only when new environmental legislation is being put through but also to facilitate efficient implementation of current legislation (Dunlap 1995). For practical reasons, it is thus important to inquire into the direction and strength of public support concerning shaping of environmental policies (Pietsch and McAllister 2010). Environmental policy attitudes may be categorized based on various criteria, for instance types of environmental issues (i.e. pollution, resources) or based on a geographical scale (i.e. local, national, global) (Pakulski et al. 1998, Konisky et al. 2008).

This paper focuses on the public support of two selected environmental issues - climate protection and wildlife protection within the Czech Republic. These topics represent different types of environmental issues associated with different geographical scales. Global climate change and hence also the climate protection is rather a global issue by its nature, which is usually perceived as geographically more distant (Koger and Winter 2011). Climate change is connected with natural processes that are not so easily imaginable and understandable for the public (Koger and Winter 2011). However, global climate change represents a big threat for nature and society, which will also directly affect inhabitants of the Czech Republic. On the other hand, wildlife protection was defined in our research at the national level of the Czech Republic so that it is geographically closer and imaginable for the citizens and so that they were able to easily relate to specific issues associated with wildlife protection, such as the protection of particular areas or endangered species or they had first-hand recreational experience with the wildlife areas. The distinction described here provides a unique and interesting opportunity to compare both areas.

To our knowledge, no similar research has been undertaken on the international scale yet, analysing and comparing these two issues based on detailed nationally representative data. However, in the practice of environmental politics both issues are often addressed by the same environmental authorities, such as the Ministry of the Environment or the State Environmental Fund of the Czech Republic. Also other political actors (e.g. political parties and politicians, NGOs) focusing on environmental politics often deal with both of these topics and reflect to what extent the public supports conservation activities within these agendas and what segments of society provide the ground for this support. All these actors also explore the ways how to acquire public acceptance and support for the measures and activities they propose, therefore it is crucial that they know the characteristics of and differences between the relevant segments.

For this very reason we are interested in the differences between the segments of the public supporting wildlife protection, climate protection, protection in both issues and protection in neither of these kinds of protection. In this context we are asking another question, which sociocultural variables influence support of climate protection or support of wildlife protection among Czech public and whether these two sets of variables differ or not. The goal of the analysis therefore is how the degree of support to these two significant environmental agendas on the part of the public differs and which characteristics differentiate the groups supporting them. 
Envigogika: Charles University E-journal for Environmental Education ISSN 1802-3061

We are using data from a nationally representative survey conducted in the Czech Republic in 2015 to analyse the public support of two selected environmental issues - climate protection and wildlife protection. The Czech Republic is a post-communist country belonging to the region of Central and Eastern Europe, which can be in comparison to North American or western European countries still characterized as understudied in terms of research exploring public opinion about the environmental issues and relevant factors which are influencing them (Marquart-Pyatt 2012). While climate change has been covered at least by several international studies including Central and Eastern European countries (e.g. Kvaløy et al. 2012, Tjernström and Tietenberg 2008, McCright et al. 2016) wildlife protection in this region has not been paid any attention. The goal of the present study is to fill in this gap and to supplement studies focusing on North America and Western Europe. We will interpret our findings in the broader context of the Czech Republic as a post-communist country within Central and Eastern Europe.

We have designed a complex and comprehensive survey, which apart from the parts dedicated to climate protection and wildlife protection included sections measuring relevant sociocultural variables crucial for the analysis. Apart from variables commonly included in the previous research dealing with factors influencing attitudes towards climate change or wildlife protection, such as sociodemographic variables, political orientation or environmental beliefs, we are paying closer attention to value orientations of the public and we added a variable measuring the amount of leisure time spent in nature, which has the potential to affect environmental attitudes (see Kals et al. 1999, Bögeholz 2006, Berns and Simpson 2009) and is relevant in the context of Czech society due to the long-term popularity of outdoor recreation in the country ${ }^{1}$. Therefore the combination of the variables used in this study is unprecedented and original even within the context of research pursued in other, more thoroughly analysed societies.

\section{The Czech Republic: context and development}

We regard it as necessary to at least briefly outline the broader context and history of the Czech Republic in order to point out potential influences on public opinion regarding environmental issues. International comparative research usually classifies the Czech Republic as one of the post-communist countries of Central and Eastern Europe (Marquart-Pyatt 2012, Chaisty and Whitefield 2015, McCright et al. 2016). The very period of state socialism has had a major impact on further development of the whole region ${ }^{2}$, but it is necessary to bear in mind that the development of the individual countries in this macro-region has differed (Waller 2010).

As far as involvement of the public in environmental protection during the socialist period of Czechoslovakia is concerned, most environmental associations were centrally run and linked to the state apparatus. These organizations focused mainly on outdoor (e.g. recreational activities or hiking) and educational activities and integrated broader public through mass-participation efforts. Officially organized voluntary work contributed, for instance, to forest management or cleaning up litter. Participation was often required by schools, employers or other organizations. Independent activities, especially if they were of oppositional nature, were not allowed by the state.

\footnotetext{
${ }^{1}$ For instance, for inhabitants of the Czech Republic nature was the main reason for going on holiday in 2015 and they have mentioned this reason more frequently than citizens of any other EU countries (European Commission 2016).

2 For a more detailed account of this development in the Czech Republic see Fagin and Jehlička 1998, Fagan and Jehlicka 2003, Carmin and Jehlička 2005, Carmin and Fagan 2010, Císař 2010.
} 
Environmental issues contributed to forming an opposition against the regime and were an important factor also during the Velvet Revolution. In the period immediately following the change of regime, environmental issues received a considerably higher degree of attention, which resulted in new environmental legislation proposals, establishing of environmental organizations and their integration in the emerging civic society (Carmin and Jehlička 2005, Carmin and Fagan 2010). Nevertheless, the political course of the country changed quite soon and with Václav Klaus as a Prime Minister, the Czech Republic set out on a track of gradual decline of attention paid to environmental issues. The country went through a period of viewing environmental issues in a rather narrow way and ignoring global environmental challenges. The key features of these developments included also a decreasing political power of environmental organizations (Fagan and Jehlička 1998, Waller 2010).

In the following period, the Czech Republic gradually integrated within the political structure of Western Europe, by joining first NATO in 1999 and then the EU in 2004, which significantly shaped the nature of its civic society (see Carmin and Fagan 2010, Císaŕ 2010). Císař (2010) believes that these changes contributed to the emergence of transactional activism (see Petrova and Tarrow 2007), which does not primarily aspire to mobilize and involve the masses, being instead based on advocacy organizations capable of staging political protest (Císař 2010).

In the context of the specificities of development in post-communist countries in Central and Eastern Europe, it is also important to describe how environmental attitudes of their population differ from those of people inhabiting other regions. International comparative studies (e.g. Marquart-Pyatt 2008, Marquart-Pyatt 2012, Chaisty and Whitefield 2015) show that general environmental attitudes and behavioural intentions of citizens in post-communist countries were lower in comparison to people from advanced market democracies or developing countries.

According to Chaisty and Whitefield (2015), the support of environmental issues decreased in the post-communist region during the period under investigation (between 1993 and 2010) while it increased in advanced market democracies. The authors justify this difference by stickiness of citizen values in association with attitude stability and the ongoing legacy of the communist era still shaping people's views of politics as well as their negative experience of the transition. Marquart-Pyatt (2008) demonstrated that models representing sources of environmental concern in advanced industrial countries are largely similar to those in former communist countries. In Czech society, pro-environmental attitudes were held more frequently by women than men, by better educated and younger people, which is largely in harmony with findings from other countries. They were also more common among urban dwellers, but the influence of income was not recorded. Pro-environmental behavioural intentions were positively influenced by respondents' age and educational background but not their gender, income or urban residence, which corresponds with findings from other countries.

In another research project, Marquart-Pyatt (2012) found that while the degree of awareness of environmental threats was greater among respondents in post-communist countries compared with respondents in Western Europe, the opposite was true in terms of their willingness to make sacrifices for the environment. However, when it comes to the Czech Republic, willingness to sacrifice as well as awareness of environmental threats turned out to be the lowest one among all post-communist countries. A model for determining the social basis of awareness of environmental threats showed that in the Czech Republic, this awareness is greater among young people and urban dwellers. In contrast, other variables such as gender, attained education or income did not influence the level of awareness of environmental threats. People with higher levels of education in the Czech Republic were also more 
willing to sacrifice while other socio-demographic variables have not proved to have an influence on this variable.

\section{Climate change and wildlife protection in the Czech Republic}

The Czech Republic is the 29th biggest producer of $\mathrm{CO} 2$ emissions per capita worldwide and the third biggest polluter within the EU (data for 2019, EDGAR 2020). The two recent decades in the Czech Republic have seen more frequent incidence of extreme weather events which are usually associated with the ongoing global climate change. These included mainly floods, rain storms alternating with periods without rain, and high numbers of tropical days (OECD 2013, Pretel 2013). The Czech public debate on climate change has been under a lasting influence of the former president Václav Klaus (president 2003-2013), who has been known as a climate sceptic worldwide and who has been cooperating with international climate sceptic organizations (Plehwe 2014, Vidomus 2013).

Although Czech public opinion has approached the average level of concern about climate change in the European Union in recent years, it is still at the bottom of this list of EU countries (European Union, 2021). According to available data (Krajhanzl et al., 2021; Český rozhlas, 2021; Centrum pro výzkum veřejného mínění, 2021), more than $75 \%$ of the Czech population is aware of the threat of climate change, $68 \%$ consider it important for the Czech Republic to act against climate change (Krajhanzl et al., 2021). However, for example, only $33 \%$ would agree with a carbon tax (ibid). The Czech public still perceives other environmental problems a little more seriously, e.g., the state of the Czech landscape is considered a serious problem by $74 \%$, while $69 \%$ assess the impacts of climate change on the Czech Republic to be a serious problem (ibid).

Protected reserves' area in the Czech Republic totals $12,535.7 \mathrm{~km} 2$, i.e. $15.9 \%$ of the area of the country. Only $0.3 \%$ of the area of the country is subjected to the no interference mode of protection. In recent years there have been several public disputes regarding extending the no interference areas, foremost among them the dispute over wildlife zones in Šumava National Park, lasting for years. Conflicts regarding extending no interference areas and restrictions to foresting activities in core zones of Šumava National Park have been dividing not only local communities but Czech public as a whole. In summer 2011, logging in core zones of the National Park led to civic mobilization, blockade and anti-felling protests. Despite that nation-wide public opinion surveys from this period indicated weak support to wildlife protection (SCaC 2011, TNS Aisa 2011, 2012).

In our representative survey presented in this article (see the section methods below) we have defined the concept of 'wildlife', as accessible areas left exposed to natural development free of human interference, i.e. without construction work, foresting or agriculture. Notions of the public about the current wildlife areas were rather distorted anyway (estimated $10.2 \%$ of total area of the Czech Republic). Even in the context of these inaccurate estimates, $44 \%$ of people supported further extensions to wildlife areas, $19 \%$ of respondents were against and the remaining $37 \%$ did not have an opinion.

\section{Factors influencing attitudes to climate change and wildlife pro- tection}

In order to answer the question if sociocultural variables affecting support to climate protection and support to wildlife protection differ, a set of variables which turned out relevant in previous research must be defined. Finding connections between attitudes to climate change and a variety of social and cultural factors such as value orientation or political and environmental attitudes is a task that has been undertaken by both international (e.g. Tjernström and Tietenberg 2008, Kvaløy et al. 2012, Tranter and Booth 2015, McCright et al. 2016) and national research in the USA (e.g. Kellstedt et al. 2008, Dunlap and McCright 2008, 
Hmielowski et al. 2013, McCright et al. 2013, 2014, Marquart-Pyatt et al. 2014), Great Britain (e.g. Poortinga et al. 2011, Whitmarsh 2011, Clements 2012a, 2012b), Australia (Tranter 2011) or New Zealand (e.g. Sibley and Kurz 2013).

Among the sociodemographic variables, gender turned out to be the most consistent predictor, women being more pro-climate oriented across a variety of climate attitudes in diverse countries (e.g. McCright 2009, McCright 2010, Tranter 2011, Clements 2012a, 2012b, Kvaløy et al. 2012, Marquart-Pyatt et al. 2014, McCright et al. 2016). Most research has also confirmed negative relation between age and climate attitudes (e.g. Kellstedt et al. 2008, Tjernström and Tietenberg 2008, Tranter 2011, Sibley and Kurz 2013, McCright et al. 2013, 2014), with younger people being more pro-climate oriented. Attained level of education is another typically studied socio-demographic variable, which is associated with more mixed findings. Most research nevertheless revealed positive relation between attained level of education and specific measures of attitudes regarding climate change (e.g. Clements 2012a, Kvaløy et al. 2012, Hmielowski et al. 2013, Sibley and Kurz 2013, McCright et al. 2016). On the other hand, there are also findings suggesting that less educated respondents are more sensitive to risks associated with climate change (e.g. McCright 2009, McCright 2010, Marquart-Pyatt et al. 2014). Income is also a variable whose link with various climate-related attitudes varies across areas being studied. The largest body of research reports this relation as non-significant (e.g. Dunlap and McCright 2008, Hamilton 2008, Tranter 2011, Hmielowski et al. 2013). Some research features also a variable concerning size of respondents' place of domicile. It is usually established whether respondents live in urban or rural areas and research has shown that urban respondents had significantly higher levels of beliefs and concern related to climate change than rural respondents (e.g. Reser et al. 2012, Tranter 2014), who were, in turn, more sceptical about climate change (Whitmarsh 2011).

Another frequently studied factor is political orientation, analysed as liberal vs. conservative, left-wing vs. right-wing, or conceived in terms of party affiliation. Across all ways of measurement, political attitudes are a relatively strong predictor of climate beliefs especially in the USA (e.g. Leiserowitz 2006, Dunlap and McCright 2008, Hamilton 2008, Hmielowski et al. 2013, Marquart-Pyatt et al. 2014). Existing research has revealed a positive relation between liberalism as well as left-wing political orientation on the one hand and various proclimate attitudes on the other.

It is not surprising that environmental beliefs are another strong predictor of attitudes to climate change. These are commonly measured using the New Ecological Paradigm scale or selected items from it (e.g. Kellstedt et al. 2008, Shwom et al. 2010, Whitmarsh 2011, Clements 2012a). Pro-environmental beliefs are usually expressed in stronger attitudes concerning climate change.

Value orientation tends to be defined in varying ways in different studies, which makes comparisons difficult. Overall, research has shown that the relation between values and climate attitudes and behaviours is either as might be expected (based on the various types of values) or it is insignificant. A substantial share of the studies (e.g. Dietz et al. 2007, Shwom et al. 2010, Poortinga et al. 2011, Milfont et al. 2015) draw on Schwartz's theory of universal values (Schwartz 2005). Study by Milfont et al. (2015) showed that beliefs about climate change are strongly positively associated with higher level of self-transcendence values and to some extent also with openness to change values. This corresponds with the results of Poortinga et al. (2011), who showed that individuals with self-transcendence values are more likely to believe that the climate is changing and expressed lower levels of climate change scepticism. On the other hand, individuals with traditional (conservation) values expressed 
higher levels of climate scepticism. According to Shwom et al. (2010) altruism (self-transcendence) increases support for policies against climate change, while traditional (conservation) values tends to reduce policy support.

Another group of studies drawing on Inglehart's theory of values (1997) and measuring material and post-material values found that preferences for post-materialist values are associated with concern for climate change (Tranter 2011, Kvaløy et al. 2012, Tranter and Booth 2015) and support for policies addressing climate change (Tranter 2011).

Other socio-cultural variables tend to feature in research less frequently. One of them is trust in experts, such as scientists, government agencies or non-profit organizations. Trust in scientists as a source of information about climate change or environment generally turned out to be positively associated with attitudes to climate change (e.g. Hmielowski et al. 2013, Kellstedt et al. 2008, Malka et al. 2009). Dietz et al. (2007) also showed that greater trust in environmental groups result increases the support for climate change policy.

A study by McCright et al. (2016) extended the presented line of research into the EU region with the aim to determine whether within the European Union there is a left-right ideological divide on climate change views. While in Western-European countries the influence of political ideology on all five climate variables ${ }^{3}$ was confirmed, in post-communist countries political ideology influenced only personal willingness to pay to fight for climate change. Moreover, this influence had an effect contrary to expectations because right-wing respondents were more willing to pay to fight for climate change. For other variables (gender, age, education) findings for Western Europe were consistent with previous studies while the effects were less pronounced and less consistent in post-communist countries. In this region, gender and education were significant predictors for three climate variables, with women and more educated people having more pro-climate attitudes. Age did prove to be a significant predictor for up to four variables but in various directions. Younger people were more sensitive to seriousness of climate change and were also more willing to pay to fight climate change. On the other hand, the conviction that climate change has anthropogenic causes and beliefs about fighting climate change were growing with growing age.

Finding connections between attitudes to wildlife protection and various socio-cultural variables has received much less attention so far than attitudes to climate protection. It is true that several local and regional studies exploring the influence of socio-demographic characteristics on perceptions of wildlife are available but detailed meta-analyses synthesizing these findings across geographical areas are still missing (Bauer et al. 2009, Edwards et al. 2012) and the studies dealing with nature and landscape type preferences (see Kaltenborn and Bjerke 2002, De Groot and van den Born 2003, Van den Berg and Koole 2006, Buijs et al. 2009) are not so relevant in the context of our research.

Bauer et al. (2009) point out that support for wildlife protection and similar attitudes differ across regions, ethnic and age groups and are also influenced by other factors such as occupational background or degree of environmental concern (see Lutz et al. 1999, Cordell et al. 2003, Johnson et al. 2004, Haukeland et al. 2013). Johnson et al. (2004) found out that support for wildlife in its natural state ${ }^{4}$ is stronger among women, among younger people, people living in urban settings and less educated people. According to another research

\footnotetext{
${ }^{3}$ These were: Acceptance of anthropogenic climate change index; Perceived seriousness of climate change; Beliefs about fighting climate change index; Personal willingness to pay to fight climate change; Support for EU greenhouse gas emissions reduction policies index.

${ }^{4}$ The paper works with 10 different wilderness value items from among which we chose an item inquiring into wildlife protection support: I support protecting wilderness just so they will always exist
} 
from US (Cordell et al. 2003) significantly more urban than rural residents as well as younger rather than older citizens support the extension of wildlife areas. Less support to wildlife protection among rural residents has been documented also by Bauer et al. 2009, which is however in conflict with research by Lutz et al. 1999, which found attitudes to wildlife protection not to differ between rural and urban residents.

Haukeland et al. (2013) focused on the acceptance of potential negative influence on wildlife and realized that the longer a respondent had spent in education, the less likely he or she was to accept negative ecological impacts. The effect of gender was confirmed in one of the two population samples, as lower toleration of these influences among women. The age of respondents, on the other hand, had no influence on the degree of toleration for negative effects on wildlife. Besides that, higher degrees of environmental beliefs as measured by the New Ecological Paradigm scale were associated with lower toleration of negative ecological impacts.

Since the number of relevant studies is limited, we can only state that the influence of demographic variables on support to wildlife protection is considerably varying across research.

\section{Methods}

The research presented in this paper attempts to answer two questions: What are the differences between groups of the public supporting wildlife protection, climate protection, protection in both these issues and neither of these kinds of protection? Is public support for climate protection influenced by the same (or different) sociocultural variables as wildlife protection?

\section{Sample population}

The data for this study has been collected within two large research projects focused on attitudes and behaviour of Czech public towards wildlife protection and climate protection, undertaken by the authors of the present study and their colleagues from the Department of Environmental Studies, Masaryk University.

The questionnaire survey was performed on a national representative sample of 2,023 respondents aged 18 or more. Respondents were approached based on quota sampling by age, gender, education, and municipality location and size (see Appendix A). The questioning was performed by trained and supervised interviewers employed by the agency using the paper-and-pencil method in respondents' homes between 19 May and 4 June 2015.

\section{Measures}

As a follow-up the review of existing research, we developed a questionnaire with a comprehensive range of socio-cultural variables as independent variables. Compared with most existing research, we included also trust in non-profit organizations and in science \& research institutions and explored value orientation in more detail. Our new addition is the amount of leisure time spent in nature - in order to monitor if the amount of recreation in nature is reflected in support of the two environmental agendas under investigation, or just

in their natural condition, even if no one were to ever visit or otherwise benefit from them (Johnson et al. 2004). 
in support to wildlife protection, which is more closely linked with recreation in nature. Our choice of dependent variables includes variables characterizing climate protection and wildlife protection. A detailed overview of the variables including how the questions were formulated and the basic characteristics is given in Appendix B.

The socio-cultural variables considered in the research included socio-demographic variables such as gender, age, education and size of respondents' place of domicile. To account for respondents' political involvement, we checked their participation in elections (communal, parliamentary, presidential, and to the European Parliament). Respondents' political orientation was determined using their election preferences. The choice of a preferred political subject (political party or movement) was coded analogically to ISSP surveys (ISSP Research Group 2012, 2015), i.e. on the scales left-wing-right-wing and liberal-conservative (considering findings by Chytilek and Eibl 2011). Based on how their election preferences were decoded, respondents were assigned values within two variables representing their tendency to choose right-wing or left-wing and liberal or conservative political agents.

We also explored respondents' trust in non-profit organizations and science \& research institutions as the subjects most frequently communicating with Czech public about climate protection and wildlife protection.

The socio-demographic and political variables were supplemented by respondents' value orientation, elicited through Schwartz's Portrait Values Questionnaire (PVQ, Schwartz $2001,2005,2012$ ) namely its 21 -item version. The test measures 10 value subscales and 4 meta-value subscales defined by Shalom Schwartz (see Table 2). Reliability testing of these subscales has shown in agreement with the conclusions by the author of the questionnaire (Schwartz 2005) that reliability of both value subscales and meta-value subscales was low and items of the individual subscales were weakly correlated. This is why we, like other authors (Krystallis et al. 2009, Havasi 2012, Defenderfer 2005) conducted PVQ factor analysis, which identified four factors: altruism, ego-motivation, security, and norm-based self-limitation (see Table 1). This result (see Table 2) corresponds with some other research findings: for instance, parallels to the ego-motivation factor connecting self-enhancement and openness to change meta-values (Krystallis et al. 2009, Havasi 2012, Defenderfer 2015), or to the altruism factor, which is correlated with self-transcendence and partly also with conservation (cf. Havasi 2012, Krystallis et al. 2009), can be found.

To establish respondents' attitude to nature, we used two scales: New Ecological Paradigm, measuring one's environmental beliefs (Dunlap et al. 2000), and several questions on leisure-time activities in nature adopted from research by Reser et al. (2012).

The dependent variables concern wildlife protection and climate protection. Searching for the answers to the first research question, we established respondents' consent with climate protection (following Ashworth et al. 2011) and their consent with wildlife protection. 
Table 1: Factor analysis PVQ

Rotated Component Matrix ${ }^{\mathrm{a}}$

\begin{tabular}{|c|c|c|c|c|}
\hline & \multicolumn{4}{|c|}{ Component } \\
\hline & 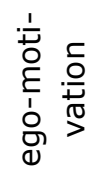 & $\begin{array}{l}\frac{E}{n} \\
\frac{1}{2} \\
\frac{1}{\pi}\end{array}$ & 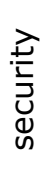 & 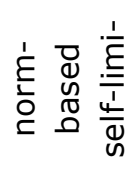 \\
\hline $\begin{array}{l}\text { Being very successful is important to him. He li- } \\
\text { kes to impress other people. }\end{array}$ & .829 & & & \\
\hline $\begin{array}{l}\text { It's very important to him to show his abilities. } \\
\text { He wants people to admire what he does. }\end{array}$ & .785 & & & \\
\hline $\begin{array}{l}\text { It is important to him to be rich. He wants to } \\
\text { have a lot of money and expensive things. }\end{array}$ & .723 & & & \\
\hline $\begin{array}{l}\text { He looks for adventures and likes to take risks. } \\
\text { He wants to have an exciting life. }\end{array}$ & .709 & & & \\
\hline $\begin{array}{l}\text { It is important to him to be in charge and tell } \\
\text { others what to do. He wants people to do what } \\
\text { he says. }\end{array}$ & .700 & & & \\
\hline $\begin{array}{l}\text { He likes surprises and is always looking for new } \\
\text { things to do. He thinks it is important to do lots } \\
\text { of different things in life. }\end{array}$ & .687 & & & \\
\hline $\begin{array}{l}\text { Thinking up new ideas and being creative is im- } \\
\text { portant to him. He likes to do things in his own } \\
\text { original way. }\end{array}$ & .670 & & & \\
\hline $\begin{array}{l}\text { Having a good time is important to him. He likes } \\
\text { to 'spoil' himself. }\end{array}$ & .663 & & & \\
\hline $\begin{array}{l}\text { He seeks every chance he can to have fun. It is } \\
\text { important to him to do things that give him plea- } \\
\text { sure. }\end{array}$ & .562 & & & \\
\hline $\begin{array}{l}\text { It is important to him to make his own decisions } \\
\text { about what he does. He likes to be free and not } \\
\text { depend on others. }\end{array}$ & .441 & & & \\
\hline $\begin{array}{l}\text { It's very important to him to help the people } \\
\text { around him. He wants to care for their well- } \\
\text { being. }\end{array}$ & & .732 & & \\
\hline $\begin{array}{l}\text { He strongly believes that people should care for } \\
\text { nature. Looking after the environment is impor- } \\
\text { tant to him. }\end{array}$ & & .689 & & \\
\hline $\begin{array}{l}\text { It is important to him to listen to people who are } \\
\text { different from him. Even when he disagrees with } \\
\text { them, he still wants to understand them. }\end{array}$ & & .686 & & \\
\hline $\begin{array}{l}\text { It is important to him to be loyal to his friends. } \\
\text { He wants to devote himself to people close to } \\
\text { him. }\end{array}$ & & .671 & & \\
\hline $\begin{array}{l}\text { He thinks it is important that every person in the } \\
\text { world be treated equally. He believes everyone } \\
\text { should have equal opportunities in life. }\end{array}$ & & .527 & & \\
\hline $\begin{array}{l}\text { Tradition is important to him. He tries to follow } \\
\text { the customs handed down by his religion or his } \\
\text { family. }\end{array}$ & & .434 & & .407 \\
\hline
\end{tabular}


It is important to him that the government insure his safety against all threats. He wants the state to be strong so it can defend its citizens. It is important to him to live in secure surroundings. He avoids anything that might endanger his safety.

He believes that people should do what they're told. He thinks people should follow rules at all times, even when no one is watching.

It is important to him to be humble and modest. He tries not to draw attention to himself.

It is important to him always to behave properly. He wants to avoid doing anything people would say is wrong.

\begin{tabular}{|c|c|c|}
\hline & .716 & \\
\hline & .681 & \\
\hline & & .644 \\
\hline .412 & & .492 \\
\hline .474 & & .489 \\
\hline & & \\
\hline
\end{tabular}

\begin{tabular}{|l|c|c|c|c|}
\hline Eigenvalue & 5.162 & 4.254 & 1.263 & 1.086 \\
\hline Variance & $24.58 \%$ & $20.26 \%$ & $6.02 \%$ & $5.17 \%$ \\
\hline Total variance explained & $24.58 \%$ & $44.4 \%$ & $50.85 \%$ & $56.02 \%$ \\
\hline
\end{tabular}

Extraction Method: Principal Component Analysis. Rotation Method: Varimax with Kaiser Normalization. Rotation converged in 7 iterations. $\mathrm{N}=1985$. Factor loadings $<0.4$ not listed.

Table 2: Correlations of PVQ factors with PVQ subscales

\begin{tabular}{|c|c|c|c|c|}
\hline \multirow[t]{2}{*}{ Pearson Correlation } & \multicolumn{4}{|c|}{ factors } \\
\hline & $\begin{array}{l}\text { ego-motiva- } \\
\text { tion }\end{array}$ & altruism & security & $\begin{array}{l}\text { norm-based } \\
\text { self-limitation }\end{array}$ \\
\hline universalism value & & 0.84 & & \\
\hline benevolence value & & 0.81 & & \\
\hline conformity value & & 0.45 & & 0.68 \\
\hline tradition value & & 0.52 & & 0.55 \\
\hline security value & & & 0.81 & \\
\hline power value & 0.86 & & & \\
\hline achievement value & 0.89 & & & \\
\hline hedonism value & 0.72 & & & \\
\hline stimulation value & 0.78 & & & \\
\hline self-direction value & 0.68 & & & \\
\hline $\begin{array}{l}\text { openness to change meta-va- } \\
\text { lue }\end{array}$ & 0.87 & & & \\
\hline conservation meta-value & & 0.54 & 0.52 & 0.61 \\
\hline self-enhancement meta-value & 0.95 & & & \\
\hline $\begin{array}{l}\text { self-transcendence meta-va- } \\
\text { lue }\end{array}$ & & 0.80 & & \\
\hline
\end{tabular}

The table only states values over 0.4 and below -0.4 .

Our operationalization of the dependent variables in connection with the second research question was based on variables constructed by us which included several dimensions 
of support for the given environmental agenda. We calculated the variable expressing overall climate protection on the basis of three reliable scales (see Appendix B): scale of concern for climate change (using items taken over from Ashworth et al. 2011), scale of conviction about political responsibility of public life participants regarding climate protection (following Reser et al. 2012), and scale of personal involvement in climate protection. We then performed factor analysis of these scales, which identified one factor with eigenvalue over 1 (see Table 3 ). The score of this factor expresses overall support for climate protection by the respondent.

Table 3: Support to climate protection factor

\begin{tabular}{|l|c|}
\hline Component Matrix & $\begin{array}{c}\text { Support to climate protection } \\
\text { factor }\end{array}$ \\
\hline Concern for climate change & .924 \\
\hline $\begin{array}{l}\text { Conviction of political responsibility for climate pro- } \\
\text { tection }\end{array}$ & .928 \\
\hline Personal involvement in climate protection & .735 \\
\hline Eigenvalue & 2.256 \\
\hline$\%$ of Variance & $75.21 \%$ \\
\hline
\end{tabular}

Extraction Method: Principal Component Analysis. $\mathrm{N}=1973$. Factors with eigenvalue $<1.0$ not listed.

Overall support for wildlife protection was operationalized likewise and the factor combining concern for wildlife (following Perceived Risks to Forest Biodiversity by McFarlane, 2005), conviction about political responsibility of public life participants regarding climate protection (following Reser et al. 2012) and personal involvement in wildlife protection was explored by factor analysis. These three scales are reliable and the factor analysis revealed, for wildlife protection as well, one factor with an eigenvalue over 1 (see Table 4). This score expresses overall support for wildlife protection.

Table 4: Support to wildlife protection factor

\begin{tabular}{|l|c|}
\hline Component Matrix & $\begin{array}{c}\text { Support to wildlife protection } \\
\text { factor }\end{array}$ \\
\hline Concern about wildlife & .768 \\
\hline Conviction of political responsibility for wildlife protection & .769 \\
\hline Personal involvement in wildlife protection & .611 \\
\hline Eigenvalue & 1.554 \\
\hline$\%$ of Variance & $51.81 \%$ \\
\hline
\end{tabular}

Extraction Method: Principal Component Analysis. $\mathrm{N}=2013$. Factors with eigenvalue $<1.0$ not listed.

\section{Statistical analyses}

To be able to answer the first question we had to compare the sample populations. We divided respondents into four groups by the level of their consent with climate protection and wildlife protection (see Table 5). Since some independent variables are ordinal ones and others interval ones, we compared the groups using the non-parametric Kruskal-Wallis test 
and parametrical ANOVA test. Because both analyses identified the same variables as differing significantly, only the result of non-parametric Kruskal-Wallis test is reported in this paper. From the perspective of environmental protection actors (politicians, ministries, public administration, NGOs) and their communication towards the public, it is worth to compare two groups each of which supports only one of the environmental agendas under investigation, i.e. to compare supporters of wildlife protection and supporters of climate protection. This comparison utilizes a non-parametric Mann-Whitney $U$ test (the result was the same as with the parametric t-test).

Table 5: Sample population division according to their consent with climate protection and consent with wildlife protection

\begin{tabular}{|c|c|c|c|c|}
\hline & \multicolumn{2}{|c|}{ Consent with climate protection } & \multirow[t]{2}{*}{ Total } \\
\hline & & $\begin{array}{l}\text { totally agree }+ \text { ra- } \\
\text { ther agree }\end{array}$ & other answers & \\
\hline \multirow[t]{2}{*}{$\begin{array}{l}\text { Consent with wildlife } \\
\text { protection }\end{array}$} & $\begin{array}{l}\text { definitely yes + ra- } \\
\text { ther yes }\end{array}$ & $31.04 \%$ & $39.89 \%$ & $70.93 \%$ \\
\hline & other answers & $6.67 \%$ & $22.39 \%$ & $29.07 \%$ \\
\hline \multicolumn{2}{|l|}{ Total } & $37.72 \%$ & $62.28 \%$ & $100.00 \%$ \\
\hline
\end{tabular}

The answer to the second question was explored by standard multiple regression analysis. The first step involved standard regression analysis (the enter method), which is a simultaneous analysis of relationships of the individual independent variables included in the model with the dependent variable. The analysis was then replicated by the stepwise analysis method, which keeps adding one independent variable after another to the model, the order being determined by the strength of their relationship with the dependent variable. The model includes only variables which have a statistically significant relationship with the dependent variable.

\section{Results}

What are the differences between groups of the public supporting wildlife protection, climate protection, protection in both these issues, or neither of these kinds of protection?

Table 5 shows that significantly more Czech people agree that wildlife should be protected than there are people supporting climate protection: while $39.9 \%$ of people not supporting climate protection do support wildlife protection, the opposite share is only $6.7 \%$. Both kinds of protection are simultaneously supported by $31 \%$ of population, neither is supported by $22.4 \%$. The following analysis shows how these four groups differ (see Table $6)$. 
Table 6: Group comparison by Kruskal-Wallis test by consent with wildlife protection and climate protection

\begin{tabular}{|c|c|c|c|c|c|c|c|c|c|c|}
\hline & Chi-Square & Asymp. Sig. & $\begin{array}{l}\text { Mean for } \\
\text { group: } \\
\text { wildlife pro- } \\
\text { tection } 0 \\
\text { climate } \\
\text { protection } 0\end{array}$ & $\begin{array}{l}\text { Mean for } \\
\text { group: } \\
\text { wildlife pro- } \\
\text { tection + } \\
\text { climate } \\
\text { protection } 0\end{array}$ & $\begin{array}{l}\text { Mean for } \\
\text { group: } \\
\text { wildlife pro- } \\
\text { tection } 0 \\
\text { climate } \\
\text { protection + }\end{array}$ & $\begin{array}{l}\text { Mean for } \\
\text { group: } \\
\text { wildlife pro- } \\
\text { tection + } \\
\text { climate } \\
\text { protection. }\end{array}$ & $\begin{array}{l}\text { Mean to- } \\
\text { tal }\end{array}$ & Min & Max & $\mathrm{N}$ \\
\hline Gender & 3.53 & .317 & 1.48 & 1.51 & 1.56 & 1.53 & 1.51 & 1.00 & 2.00 & 2023 \\
\hline Age & 1.98 & .576 & 46.86 & 46.38 & 47.69 & 45.81 & 46.40 & 18.00 & 88.00 & 2023 \\
\hline Education & 31.02 & .000 & 2.36 & 2.52 & 2.61 & 2.75 & 2.56 & 1.00 & 5.00 & 2023 \\
\hline Place of domicile size & 5.83 & .120 & 3.41 & 3.65 & 3.60 & 3.68 & 3.60 & 1.00 & 7.00 & 2023 \\
\hline $\begin{array}{l}\text { Net monthly per capita } \\
\text { household income (in } \\
\text { CZK) }\end{array}$ & 3.81 & .283 & 12646.53 & 13350.88 & 13433.34 & 12888.08 & 13052.67 & 0.00 & 60000.00 & 1658 \\
\hline Participation in elections & 57.97 & .000 & 0.45 & 0.53 & 0.64 & 0.63 & 0.55 & 0.00 & 1.00 & 1961 \\
\hline Left-right scale & 10.756 & .013 & 1.69 & 1.82 & 1.87 & 1.85 & 1.81 & 1.00 & 3.00 & 1315 \\
\hline Liberal-conservative scale & 6.170 & .104 & 2.09 & 2.02 & 2.04 & 1.97 & 2.02 & 1.00 & 3.00 & 1315 \\
\hline $\begin{array}{l}\text { Trust in scientific and re- } \\
\text { search institutions }\end{array}$ & 41.18 & .000 & 6.13 & 6.45 & 7.01 & 6.99 & 6.59 & 0.00 & 10.00 & 1924 \\
\hline $\begin{array}{l}\text { Trust in non-profit organi- } \\
\text { zations }\end{array}$ & 49.07 & .000 & 4.98 & 5.52 & 5.87 & 6.06 & 5.60 & 0.00 & 10.00 & 1871 \\
\hline Security factor & 5.16 & .161 & -0.01 & -0.04 & 0.12 & 0.03 & 0.00 & -4.89 & 3.01 & 1985 \\
\hline Altruism factor & 126.10 & .000 & -0.38 & -0.02 & -0.02 & 0.31 & 0.00 & -4.00 & 3.00 & 1985 \\
\hline Ego-motivation factor & 1.64 & .651 & -0.06 & -0.01 & 0.05 & 0.05 & 0.00 & -3.27 & 2.57 & 1985 \\
\hline Conformity factor & 10.85 & .013 & 0.07 & -0.06 & 0.21 & -0.02 & 0.00 & -4.52 & 3.43 & 1985 \\
\hline Leisure time in nature & 124.23 & .000 & 3.57 & 4.16 & 4.56 & 4.64 & 4.20 & 1.00 & 7.00 & 2017 \\
\hline New Ecological Paradigm & 280.40 & .000 & 3.16 & 3.42 & 3.42 & 3.70 & 3.45 & 1.53 & 4.93 & 2023 \\
\hline
\end{tabular}


The comparison of the four groups structured by their support/lack of support for climate protection and wildlife protection indicates that most statistically significant differences within variables differentiates the individual groups of the public on the scale, from the group supporting neither of the agendas, through the group supporting only wildlife protection and the group supporting only climate protection, to the group supporting both protection agendas. This concerns education background, trust in non-profit organizations, altruism, leisure time spent in nature and environmental beliefs (NEP). A similar trend can be observed within election participation, right-wing political orientation and trust in scientific \& research organizations, for which however group mean values of the group supporting only climate protection are nearly identical with those of the group supporting both agendas. Exceptions from this trend are only the differences in the norm-based self-limitation factor. No statistically significant differences regarding gender, age, place of domicile size, net monthly household income, liberal versus conservative orientation, security factor and ego-motivation factor were observed.

Table 7: Group comparison by Mann-Whitney U test by consent with wildlife protection and climate protection

\begin{tabular}{|l|r|r|r|r|}
\hline & $\begin{array}{l}\text { Mann- } \\
\text { Whitney U }\end{array}$ & $\begin{array}{l}\text { Wilcoxon } \\
\text { W }\end{array}$ & Z & $\begin{array}{l}\text { Asymp. } \\
\text { Sig. (2- } \\
\text { tailed) }\end{array}$ \\
\hline Gender & 51751.50 & 377779.50 & -1.07 & .283 \\
\hline Age & 51685.50 & 377713.50 & -0.95 & .341 \\
\hline Education & 51173.50 & 377201.50 & -1.18 & .236 \\
\hline Place of domicile size & 54161.00 & 63341.00 & -0.11 & .914 \\
\hline Net monthly per capita income (in CZK) & 35728.50 & 41944.50 & -0.21 & .830 \\
\hline Participation in elections & 44368.50 & 345844.50 & -2.95 & .003 \\
\hline Left-right scale & 23720.00 & 160223.00 & -.73 & .467 \\
\hline Liberal-conservative scale & 24277.00 & 160780.00 & -.37 & .712 \\
\hline Trust in scientific and research institutions & 42850.50 & 338146.50 & -2.35 & .019 \\
\hline Trust in non-profit organizations & 43519.00 & 319172.00 & -1.53 & .127 \\
\hline Security factor & 46851.50 & 358506.50 & -1.85 & .065 \\
\hline Altruism factor & 52022.50 & 363677.50 & -0.02 & .985 \\
\hline Ego-motivation factor & 50187.50 & 361842.50 & -0.67 & .505 \\
\hline Conformity factor & 43679.50 & 355334.50 & -2.97 & .003 \\
\hline Leisure time in nature & 46638.00 & 369444.00 & -2.60 & .009 \\
\hline New Ecological Paradigm & 53842.00 & 63022.00 & -0.22 & .829 \\
\hline
\end{tabular}

As the comparison using the Mann-Whitney $U$ test shows (Table 7), groups of people who support only climate protection or only wildlife protection, are differentiated by several socio-cultural variables. Those who only agree with climate protection turn up for elections statistically more frequently, have more trust in scientific and research institution, show more norm-based self-limitation and spend more time in nature. It is worth noticing that New Ecological Paradigm does not differentiate between these two groups.

Is support for climate protection among Czech people enhanced by the same (or different) sociocultural variables that enhance wildlife protection?

To compare the socio-cultural variables influencing overall support for climate protection and wildlife protection, we performed standard regression analysis: first the enter 
method was used (see Table 8) and then we replicated it using the stepwise method (see Table 9).

Table 8: Regression analyses (enter technique) of overall support to climate protection and wildlife protection

\begin{tabular}{|c|c|c|}
\hline & $\begin{array}{l}\text { Overall support to } \\
\text { climate protection }\end{array}$ & $\begin{array}{l}\text { Overall support to } \\
\text { wildlife protection }\end{array}$ \\
\hline & $\begin{array}{c}\text { Standardized Beta } \\
\text { Coefficients }\end{array}$ & $\begin{array}{l}\text { Standardized Beta } \\
\text { Coefficients }\end{array}$ \\
\hline Gender & .02 & .04 \\
\hline Age & $-0.06 *$ & .00 \\
\hline Education & .04 & .02 \\
\hline Place of domicile size & .03 & .04 \\
\hline Net monthly per capita household income (in CZK) & -.05 & -.02 \\
\hline Participation in elections & $0.09 * * *$ & .03 \\
\hline Left-right scale & $-0.08^{*}$ & -.02 \\
\hline Liberal-conservative scale & -.03 & -.03 \\
\hline Trust in scientific and research institutions & -.01 & $-0.13 * * *$ \\
\hline Trust in non-profit organizations & -.01 & $0.15 * * *$ \\
\hline Security factor & .01 & .03 \\
\hline Altruism factor & $0.08^{* *}$ & $0.13 * * *$ \\
\hline Ego-motivation factor & .02 & .06 \\
\hline Conformity factor & .02 & .02 \\
\hline Leisure time in nature & $0.14 * * *$ & $0.14 * * *$ \\
\hline New Ecological Paradigm & $0.39 * * *$ & $0.38^{* * *}$ \\
\hline Adjusted R Square & .257 & .269 \\
\hline
\end{tabular}

The statistically significant values are marked with an asterisk: $* p<0.05, * * p<0.01$, $* * * \mathrm{p}<0.001$.

The results of both analyses show that overall support for climate protection and wildlife protection is most strongly enhanced by overall pro-environmental beliefs of respondents (New Ecological Paradigm), by leisure time spent in nature and altruism (for wildlife protection more than for climate protection). Both agendas however have specifics of their own. Overall support for wildlife protection is increasing with the growing trust in non-profit organizations, and, interestingly, it is decreasing with growing trust in science \& research institutions. Overall support for climate protection is growing with increasing election participation, left-wing orientation and decreasing age. The use of enter and stepwise methods yielded the same results, with the only exception: the stepwise method showed that growing egomotivation weakly but statistically significantly increase support for wildlife protection. 
Table 9: Regression analyses (stepwise technique) of overall support to climate protection and wildlife protection

\begin{tabular}{|l|c|c|}
\hline & $\begin{array}{c}\text { Overall support to } \\
\text { climate protection }\end{array}$ & $\begin{array}{c}\text { Overall support to } \\
\text { wildlife protection }\end{array}$ \\
\hline & $\begin{array}{c}\text { Standardized Beta } \\
\text { Coefficients }\end{array}$ & $\begin{array}{c}\text { Standardized Beta } \\
\text { Coefficients }\end{array}$ \\
\hline Age & $-0.08^{* *}$ & \\
\hline Participation in elections & $0.10^{* * *}$ & \\
\hline Left-right scale & $-0.06^{*}$ & $-0.13^{* * *}$ \\
\hline $\begin{array}{l}\text { Trust in scientific and research } \\
\text { institutions }\end{array}$ & & $0.15^{* * *}$ \\
\hline Trust in non-profit organizations & & $0.14^{* * *}$ \\
\hline Altruism factor & $0.09^{* *}$ & $0.06^{*}$ \\
\hline Ego-motivation factor & & $0.13^{* * *}$ \\
\hline Leisure time in nature & $0.14^{* * *}$ & $0.39^{* * *}$ \\
\hline New Ecological Paradigm & $0.39^{* * *}$ & 0.269 \\
\hline Adjusted R Square & 0.259 & \\
\hline
\end{tabular}

Models including all significant variables. The statistically significant values are marked with an asterisk: $* \mathrm{p}<0.05, * * \mathrm{p}<0.01, * * * \mathrm{p}<0.001$.

\section{Discussion}

Respondents' answers to questions inquiring about their degree of support to wildlife protection and climate protection showed that support for wildlife protection is much more common among Czech public (total support 70.9\%) than support for climate protection $(37.7 \%)$. Both protection agendas are supported by nearly one third of respondents and, conversely, less than one quarter of people support neither of them. A large part of the public thus supports wildlife protection without supporting climate protection $(39.9 \%)$ while there were quite few respondents to support climate protection only (6.7\%) (see Table 5).

The comparison of all four groups defined according to their consent with climate protection and wildlife protection revealed statistically significant differences in nine out of sixteen socio-cultural variables under analysis (see Table 6 ). The two groups supporting one protection agenda only differ significantly in four variables (see Table 7). The identified pattern describing differences among the groups (see section Results) exposed that the group supporting protection within both agendas is more similar to the group supporting only climate protection than to the group supporting only wildlife protection. The group supporting neither protection agenda is, on the other hand, more similar to the group supporting only wildlife protection than to the group supporting only climate protection.

Therefore we can conclude that consent with wildlife protection turns out to be a more inclusive pro-environmental attitude, while consent with climate protection can be characterized as a more exclusive pro-environmental attitude. These characteristics are in agreement with the higher level of public support for wildlife protection than climate protection by the public. These findings are also in line with the differing features of the two protection agendas we suggested in the introduction to this paper. Compared with wildlife protection, people may find climate protection more difficult to understand and imagine, more stressful and geographically more distant.

The conclusions presented above are especially important for those actors engaged in environmental politics, especially for how they approach the public. It turns out that they 
should find it easier to gain people's support of wildlife protection while winning people's support for climate protection may be more of a challenge. However, since the group of people supporting climate protection without supporting wildlife protection is relatively small, it seems quite realistic to strive for enlargement of the group supporting both protection agendas.

The results of standard regression analyses showed that some variables enhance support for both protection issues while other variables enhance support just for one of them. According to our assumptions both types of support are most strongly positively influenced by the overall ecological beliefs of respondents as measured by NEP, which is in line with previous studies (e.g. Shwom et al. 2010, Whitmarsh 2011, Clements 2012a, Haukeland et al. 2013). Environmental beliefs also significantly differentiate the four groups, even though there was no difference between the groups supporting only one of the protection issues.

Leisure time spent in nature also turned out to be a very strong factor influencing support for both issues. People spending their leisure time in nature are supporting wildlife and climate protection more than people who do not tend to spend their time in that way. This finding thus supports our assumption about the potential of this factor to affect environmental attitudes and its high relevance in the Czech context. As we have stated above, this variable also differentiates between the groups, with people supporting climate protection spending more leisure time in nature.

Among the value factors obtained from the Schwartz's PVQ only the altruism factor was significant in positively influencing support for both protection issues. This factor is strongly correlated with the Schwartz's self-transcendence scale (see Table 2), which was positively linked to the belief that climate is changing and negatively linked to climate scepticism in Great Britain (Poortinga et al. 2011). According to a model created by the stepwise method, including only relevant significant independent variables, support for wildlife protection is slightly influenced by the factor of ego-motivation, which highly correlates with openness to change and self-enhancement meta-values defined by Schwartz (2005). The factor of norm-based self-limitation turned out to be significant in differentiating between the groups.

The groups being compared also significantly differ in terms of trust in science \& research institutions and trust in non-profit organizations, this trust being higher in groups supporting climate protection. Results worth attention revealed that support for wildlife protection increases with growing trust in non-profit organizations, but it decreases with growing trust in science \& research institutions. Support for climate protection is however not influenced by any of these kinds of trust, which does not correspond with results of previous research (Dietz et al 2007, Kellstedt et al. 2008, Malka et al. 2009 Hmielowski et al. 2013).

Political involvement measured by participation in elections and left-wing political orientation turned out to be positively influence support to climate protection, whereas no relationship was documented for the liberal-conservative scale and none of these variables had an influence on support wildlife protection. Even though the positive influence of left-wing orientation on support to climate protection corresponds with the findings from Western Europe (McCright et al. 2016), they are different from results of analysis of post-communist countries, where McCright et al. 2016 documented that right-wing orientation increases personal willingness to pay to fight for climate change. Participation in elections also differentiates between the groups significantly, which was proved in both tests.

Surprisingly, the relationship with most of the sociodemographic variables turned out to be insignificant concerning support for both protection agendas. The only one exception was age, where we found that younger people tend to support climate protection more than 
older ones, which is in line with previous studies from abroad (e.g. Sibley and Kurz 2013, McCright et al. 2013, 2014, McCright et al. 2016 for western Europe), but the findings for the post-communist countries were mixed in this respect. McCright et al. (2016) found that age negatively influenced perceived seriousness of climate change and personal willingness to pay to fight climate change, while the link was positive for acceptance of anthropogenic climate change and beliefs about fighting climate change. Studies focused directly on the Czech Republic found a negative relationship between age and environmental attitudes (MarquartPyatt 2008) or awareness of environmental threats (Marquart-Pyatt 2012). On the other hand, this relationship was positive in the case of pro-environmental behavioural intentions (Marquart-Pyatt 2008).

The documented absence of a relationship between gender or education and support for climate protection contradicts most of the previous findings from different regions (e.g. Clements 2012a, Kvaløy et al. 2012, Sibley and Kurz 2013, McCright et al. 2016) and also research within the post-communist countries by McCright et al. (2016) documented that gender and education were both significant predictors for three out of five variables. ${ }^{5}$ Studies focused on Czech society found that women more frequently hold environmental attitudes (Marquart-Pyatt 2008), but there was no relationship between gender and pro-environmental behavioural intentions (Marquart-Pyatt 2008), awareness of environmental threats or willingness to sacrifice for the environment (Marquart-Pyatt 2012), which is more in line with our findings. However, concerning the level of education these studies found positive relationships with all of the examined variables, except for awareness of the environmental threats (Marquart-Pyatt 2008, 2012). Contrary to the results of previous studies (e.g. Cordell et al. 2003, Johnson et al. 2004, Marquart-Pyatt 2008, 2012, Bauer et al. 2009) we have not detected relationship between place of domicile size and support to wildlife protection or climate protection, so it seems that whether people live in rural or urban areas does not affect their support for any of the issues.

In summary, our analysis showed that sociodemographic variables neither differentiate between the groups (except for educational background) nor significantly influence support for wildlife or climate protection (except for age). This finding has important implications for communicating both agendas to the public because there is no point in specifying the target groups based on sociodemographic variables. Our research proves it much more appropriate to define the target groups based on other variables such as environmental beliefs (measured by NEP), leisure time spent in nature, participation in elections, or trust in scientific and research institutions or non-profit organizations.

\section{Conclusion}

In this paper we have analysed and compared support for climate and wildlife protection using the data from the national representative survey undertaken in the Czech Republic. Our study thus expands the empirical research focusing on public opinion about the environmental issues within the understudied post-communist region of Central and Eastern Europe.

\footnotetext{
5 Women in comparison to men perceived climate change as more serious and had a higher level of acceptance of anthropogenic climate change as well as support for EU greenhouse gas emissions reduction policies. Level of education positively influenced perceived seriousness of climate change, beliefs about fighting climate change and personal willingness to pay for this fight.
} 
Support for wildlife protection proved to be much more widespread in Czech society than support for climate protection. The comparison of characteristics of groups defined based by their support for both protection agendas has also shown that support for wildlife protection may be characterized as the more inclusive pro-environmental attitude compared with support for climate protection, which is more exclusive. It would certainly be interesting to find out whether the situation is the same in other post-communist countries or in other regions.

Our analyses have shown that the groups do not differ in any major ways in terms of their sociodemographic characteristics (except for education) and that these variables do not influence support for climate protection or support for wildlife protection (except for negative influence of age on support for climate protection), which differs from research undertaken so far. Therefore, when addressing the public, the target groups should be defined based on other than sociodemographic characteristics. Our research succeeded in identifying new socio-cultural variables influencing the support of these protection agendas, which have not been considered in the previous studies.

Besides pro-environmental beliefs, it is leisure time spent in nature and altruism that are positively influencing support for both agendas. The four groups we have defined significantly differ in these variables; in addition, leisure time spent in nature is a factor which differentiates strongly between the group supporting only wildlife protection and the group supporting only climate protection.

It also turned out that support for wildlife protection increases with growing trust in non-profit organizations while it decreases with growing trust in science \& research institutions. Support for climate protection is growing with higher election participation and left-wing political leanings, consistent with studies undertaken in the USA.

Our research has revealed several new variables which we believe should be considered when defining target groups to communicate wildlife protection and climate protection agendas to the public and in efforts to win the public support. Including these variables in similar research in other countries may facilitate a deeper understanding of the specifics of social and cultural distribution of climate protection support and wildlife protection support or other environmental issues.

\section{Acknowledgments}

This article is one of the outputs of the project "Udržitelná a spravedlivější společnost: přístupy humanitních a sociálních věd" [Sustainable and fairer society: approaches of humanities and social sciences] (MUNI/A/1377/2020) supported by the Grant Agency of Masaryk University, Czech Republic."

We would also like to acknowledge the help we received from Mgr. Jan Skalík, Mgr. Renata Svobodová, Mgr. Karel Čada and others.

Tomáš Chabada, Jan Krajhanzl

The Department of Environmental Studies, Faculty of Social Studies, Masaryk University, Joštova 10, Brno, 602 00, Czech Republic 


\section{References}

- Ashworth, P., Jeanneret, T., Gardner, J., and Shaw, H., 2011. Communication and climate change: What the Australian public thinks. Pullenvale: CSIRO, https://core.ac.uk/download/pdf/30680968.pdf

- Bauer, N., Wallner, A., and Hunziker, M., 2009. The change of European landscapes: Human-nature relationships, public attitudes towards rewilding, and the implications for landscape management in Switzerland. Journal of Environmental Management, 90 (9), 2910-2920, https://doi.org/10.1016/j.jenvman.2008.01.021

- Berns, G.N. and Simpson, S., 2009. Outdoor recreation participation and environmental concern: A research summary. Journal of Experiential Education, 32 (1), 79-91., https://doi.org/10.1177/105382590903200107

- Bögeholz, S., 2006. Nature experience and its importance for environmental knowledge, values and action: recent German empirical contributions. Environmental Education Research, 12 (1), 65-84, https://doi.org/10.1080/13504620500526529

- Buijs, A.E., Elands, B.H.M., and Langers, F., 2009. No wilderness for immigrants: Cultural differences in images of nature and landscape preferences. Landscape and Urban Planning, 91, 113-123, https://doi.org/10.1016/j.landurbplan.2008.12.003

- Burstein, P., 2003. The impact of public opinion on public policy: A review and an agenda. Political Research Quarterly, 56 (1), 29-40, https://doi.org/10.1177/106591290305600103

- Carmin, J. and Fagan, A., 2010. Environmental mobilisation and organisations in post-socialist Europe and the former Soviet Union. Environmental Politics, 19 (5), 689-707, https://doi.org/10.1080/09644016.2010.508300

- Carmin, J. and Jehli, P., 2005. By the masses or for the masses? The transformation of voluntary action in the Czech Union for Nature Protection. Voluntas: International Journal of Voluntary and Nonprofit Organizations, 16 (4), 397-416. https://doi.org/10.1007/s11266-005-9149-8

- Centrum pro výzkum veřejného mínění, 2021. Postoje české veřejnosti ke změně klimatu na Zemi - červenec 2021 (Výzkum NS 21-07). [online]. Available from: https://cvvm.soc.cas.cz/cz/tiskove-zpravy/ostatni/vztahy-a-zivotni-postoje/5253postoje-ceske-verejnosti-ke-zmene-klimatu-na-zemi-cerven-2020 [Accessed 27 Sep 2021].

- Chaisty, P. and Whitefield, S., 2015. Attitudes towards the environment: are postCommunist societies (still) different? Environmental Politics, 24 (4), 598-616, https://doi.org/10.1080/09644016.2015.1023575

- Chytilek, R. and Eibl, O., 2011. České politické strany v politickém prostoru. Sociologickỳ časopis/Czech Sociological Review, 61-88, https://www.ceeol.com/search/article-detail?id=164818

- Císař, O., 2010. Externally sponsored contention: the channelling of environmental movement organisations in the Czech Republic after the fall of Communism. Environmental Politics, 19 (5), 736-755, https://doi.org/10.1080/09644016.2010.508305 . 
- Clements, B., 2012a. Exploring public opinion on the issue of climate change in Britain. British Politics, 7 (2), 183-202, https://doi.org/10.1057/bp.2012.1 .

- Clements, B., 2012b. The sociological and attitudinal bases of environmentally-related beliefs and behaviour in Britain. Environmental Politics, 21 (6), 901-921, https://doi.org/10.1080/09644016.2012.724215.

- Český rozhlas, 2021. Rozděleni svobodou: Klimatická změna. [online]. Available from: https://www.stem.cz/rozdeleni-svobodou-klimaticka-zmena/ [Accessed 27 Sep 2021].

- Daniels, D.P., Krosnick, J.A., Tichy, M.P., and Tompson, T., 2013. Public opinion on environmental policy in the United States. The Oxford Handbook of US Environmental Policy, 1-19.

- Defenderfer, J.A., 2015. Differences in Group Value Priorities and Their Impact on Political Candidate Support: A Consideration of Sex, Party, and Race. The Ohio State University, https://www.proquest.com/openview/8fd1700754971234f83b92caa9d4904e/1?pq-origsite=gscholar \&cbl=18750 .

- De Groot, W.T. and van den Born, R.J., 2003. Visions of nature and landscape type preferences: an exploration in The Netherlands. Landscape and Urban Planning, 63 (3), 127-138, https://doi.org/10.1016/S0169-2046(02)00184-6.

- Dietz, T., Dan, A., and Shwom, R., 2007. Support for Climate Change Policy: Social Psychological and Social Structural Influences*. Rural Sociology, 72 (2), 185-214, https://doi.org/10.1526/003601107781170026.

- Dunlap, R.E., 1995. Public opinion and environmental policy. In: Environmental politics and policy. Duke University Press, 63-114.

- Dunlap, R.E. and McCright, A.M., 2008. A widening gap: Republican and Democratic views on climate change. Environment: Science and Policy for Sustainable Development, 50 (5), 26-35, https://doi.org/10.3200/ENVT.50.5.26-35 .

- Dunlap, R.E., Van Liere, K.D., Mertig, A.G., and Jones, R.E., 2000. New trends in measuring environmental attitudes: measuring endorsement of the new ecological paradigm: a revised NEP scale. Journal of social issues, 56 (3), 425-442.

- Edwards, D., Jay, M., Jensen, F.S., Lucas, B., Marzano, M., Montagné, C., Peace, A., and Weiss, G., 2012. Public preferences for structural attributes of forests: Towards a pan-European perspective. Forest Policy and Economics, 19, 12-19, https://doi.org/10.1016/j.forpol.2011.07.006 .

- European Commission, 2016. Flash Eurobarometer 432 (Preferences of Europeans towards Tourism, 2016). TNS Political \& Social [producer]. GESIS Data Archive, Cologne.

- European Commission, 2021. Fossil CO2 emissions of all world countries [online]. Available from: https://edgar.jrc.ec.europa.eu/report 2020 [Accessed 2 Sep 2021].

- European Union, 2021. Special Eurobarometer 513: Climate change. Report (Wave EB95.1.). Dostupné z: https://europa.eu/eurobarometer/surveys/detail/2273 
- Fagan, A. and Jehlicka, P., 2003. Contours of the Czech environmental movement: a comparative analysis of Hnuti Duha (Rainbow Movement) and Jihoceske matky (South Bohemian Mothers). Environmental Politics, 12 (2), 49-70, https://doi.org/10.1080/09644010412331308184 .

- Fagin, A. and Jehlička, P., 1998. Sustainable development in the Czech Republic: A doomed process? Environmental Politics, 7 (1), 113-128, https://doi.org/10.1080/09644019808414375.

- Hamilton, L.C., 2008. Who cares about polar regions? Results from a survey of US public opinion. Arctic, Antarctic, and Alpine Research, 40 (4), 671-678, https://doi.org/10.1657/1523-0430(07-105)[HAMILTON]2.0.CO;2 .

- Havasi, V., 2012. The Place of Environment-Related Values in the Value-System. A Cross-Country Analysis1. Acta Universitatis Sapientiae. Social Analysis, 2 (2), 163183, https://www.researchgate.net/profile/Virag-Havasi/publication/330181657 The Place of Environment-Related Values in the Value-System_A_Cross-Country_Analysis_1/links/5c31f33b299bf12be3b2cc12/The-Place-ofEnvironment-Related-Values-in-the-Value-System-A-Cross-Country-Analysis-1.pdf .

- Hmielowski, J.D., Feldman, L., Myers, T.A., Leiserowitz, A., and Maibach, E., 2013. An attack on science? Media use, trust in scientists, and perceptions of global warming. Public Understanding of Science, 963662513480091, https://doi.org/10.1177/0963662513480091.

- Inglehart, R., 1997. Modernization and postmodernization: Cultural, economic, and political change in 43 societies. Princeton University Press, https://doi.org/10.1515/9780691214429-005 .

- ISSP Research Group, 2012. International Social Survey Programme: Environment III - ISSP 2010.

- ISSP Research Group, 2015. International Social Survey Programme: National Identity III - ISSP 2013.

- Johnson, C.Y., Bowker, J.M., Bergstrom, J.C., and Ken Cordell, H., 2004. Wilderness values in America: does immigrant status or ethnicity matter? Society and Natural Resources, 17 (7), 611-628, https://doi.org/10.1080/08941920490466585.

- Kals, E., Schumacher, D., and Montada, L., 1999. Emotional affinity toward nature as a motivational basis to protect nature. Environment and behavior, 31 (2), 178202, https://doi.org/10.1177\%2F00139169921972056 .

- Kaltenborn, B.P. and Bjerke, T., 2002. Associations between environmental value orientations and landscape preferences. Landscape and Urban Planning, 59 (1), 111, https://doi.org/10.1016/S0169-2046(01)00243-2 .

- Kellstedt, P.M., Zahran, S., and Vedlitz, A., 2008. Personal efficacy, the information environment, and attitudes toward global warming and climate change in the United States. Risk Analysis, 28 (1), 113-126, https://doi.org/10.1111/j.15396924.2008.01010.x.

- Koger, S.M. and Winter, D.D., 2011. The psychology of environmental problems: Psychology for sustainability. Psychology press. 
- Konisky, D.M., Milyo, J., and Richardson, L.E., 2008. Environmental policy attitudes: issues, geographical scale, and political trust. Social Science Quarterly, 89 (5), 1066-1085, https://doi.org/10.1111/j.1540-6237.2008.00574.x .

- Krajhanzl, J., Chabada, T., Svobodová, R., Kácha, O., Vintr, J. \& Becková, A., 2021. České klima 2021: Mapa českého veřejného mínění v oblasti změny klimatu. Katedra environmentálních studií FSS MU, Green Dock. [online]. Available from: https://enviro.fss.muni.cz/ceskeklima2021 [Accessed 27 Sep 2021].

- Krystallis, A., Vassallo, M., Chryssohoidis, G., and Perrea, T., 2008. Societal and individualistic drivers as predictors of organic purchasing revealed through a portrait value questionnaire (PVQ)-based inventory. Journal of Consumer Behaviour, 7 (2), 164-187, https://doi.org/10.1002/cb.244.

- Kvaløy, B., Finseraas, H., and Listhaug, O., 2012. The publics' concern for global warming: A cross-national study of 47 countries. Journal of Peace Research, 49 (1), 11-22, https://doi.org/10.1177\%2F0022343311425841.

- Leiserowitz, A., 2006. Climate change risk perception and policy preferences: The role of affect, imagery, and values. Climatic change, 77 (1-2), 45-72, https://doi.org/10.1007/s10584-006-9059-9.

- Lutz, A.R., Simpson-Housley, P., and Deman, A.F., 1999. Wilderness rural and urban attitudes and perceptions. Environment and Behavior, 31 (2), 259-266, https://doi.org/10.1177\%2F00139169921972092.

- Malka, A., Krosnick, J.A., and Langer, G., 2009. The association of knowledge with concern about global warming: Trusted information sources shape public thinking. Risk Analysis, 29 (5), 633-647, https://doi.org/10.1111/j.1539-6924.2009.01220.x

- Marquart-Pyatt, S.T., 2008. Are There Similar Sources of Environmental Concern? Comparing Industrialized Countries*. Social Science Quarterly, 89 (5), 1312-1335. https://doi.org/10.1111/j.1540-6237.2008.00567.x

- Marquart-Pyatt, S.T., 2012. Environmental concerns in cross-national context: how do mass publics in Central and Eastern Europe compare with other regions of the world? Sociologickỳ časopis/Czech Sociological Review, 441-466, https://www.ceeol.com/search/article-detail?id=262922.

- Marquart-Pyatt, S.T., McCright, A.M., Dietz, T., and Dunlap, R.E., 2014. Politics eclipses climate extremes for climate change perceptions. Global Environmental Change, 29, 246-257, https://doi.org/10.1016/j.gloenvcha.2014.10.004.

- McCright, A.M., 2009. Social Bases of Climate Change Knowledge, Concern, and Policy Support in the US General Public, The. Hofstra L. Rev., 37, 1017, https://scholarlycommons.law.hofstra.edu/cgi/viewcontent.cgi?article $=2473 \&$ context $=$ hlr. .

- McCright, A.M., 2010. The effects of gender on climate change knowledge and concern in the American public. Population and Environment, 32 (1), 66-87, https://doi.org/10.1007/s11111-010-0113-1.

- McCright, A.M., Dunlap, R.E., and Marquart-Pyatt, S.T., 2016. Political ideology and views about climate change in the European Union. Environmental Politics, 25 (2), 338-358, https://doi.org/10.1080/09644016.2015.1090371. 
- McCright, A.M., Dunlap, R.E., and Xiao, C., 2013. Perceived scientific agreement and support for government action on climate change in the USA. Climatic Change, 119 (2), 511-518, https://doi.org/10.1007/s10584-013-0704-9.

- McCright, A.M., Dunlap, R.E., and Xiao, C., 2014. Increasing influence of party identification on perceived scientific agreement and support for government action on climate change in the United States, 2006-12. Weather, Climate, and Society, 6 (2), 194-201, https://doi.org/10.1175/WCAS-D-13-00058.1 .

- McFarlane, B.L., 2005. Public Perceptions of Risk to Forest Biodiversity. Risk Analysis: An International Journal, 25 (3), 543-553, https://doi.org/10.1111/j.15396924.2005.00623.x.

- Milfont, T.L., Milojev, P., Greaves, L.M., and Sibley, C.G., 2015. Socio-structural and psychological foundations of climate change beliefs. New Zealand Journal of Psychology, 44 (1), 18, https://www.psychology.org.nz/journal-archive/Article21.pdf,

- OECD, 2013. Water and Climate Change Adaptation: Policies to Navigate Uncharted Waters. Paris: OECD Publishing.

- Pakulski, J., Tranter, B., and Crook, S., 1998. The dynamics of environmental issues in Australia: Concerns, clusters and carriers. Australian Journal of Political Science, 33 (2), 235-252, https://doi.org/10.1080/10361149850633.

- Petrova, T. and Tarrow, S., 2007. Transactional and Participatory Activism in the Emerging European Polity The Puzzle of East-Central Europe. Comparative Political Studies, 40 (1), 74-94, https://doi.org/10.1177\%2F0010414006291189.

- Pietsch, J. and McAllister, I., 2010. 'A diabolical challenge': public opinion and climate change policy in Australia. Environmental Politics, 19 (2), 217-236, https://doi.org/10.1080/09644010903574509.

- Plehwe, D., 2014. Think tank networks and the knowledge-interest nexus: the case of climate change. Critical Policy Studies, 8 (1), 101-115, https://doi.org/10.1080/19460171.2014.883859.

- Poortinga, W., Spence, A., Whitmarsh, L., Capstick, S., and Pidgeon, N.F., 2011. Uncertain climate: An investigation into public scepticism about anthropogenic climate change. Global environmental change, 21 (3), 1015-1024, https://doi.org/10.1016/j.gloenvcha.2011.03.001.

- Pretel, J., 2013. Změny klimatu v České republice: Současný vývoj a pravděpodobný výhled. Vesmír, 92, 605-609.

- Reser, J.P., Bradley, G.L., Glendon, A.I., Ellul, M.C., and Callaghan, R., 2012. Public risk perceptions, understandings and responses to climate change in Australia and Great Britain. Gold Coast, Qld: Griffith Climate Change Response Adaptation Facility, https://nccarf.edu.au/public-risk-perceptions-understandings-and-responsesclimate-change-and-natural-disaster-0/.

- SCaC., 2011. Kůrovec na Šumavě - expresní výzkum (výzkumná zpráva). Retrieved from http://img.ct24.cz/multimedia/documents/28/2767/276647.pdf 
- Shwom, R., Bidwell, D., Dan, A., and Dietz, T., 2010. Understanding US public support for domestic climate change policies. Global Environmental Change, 20 (3), 472-482, https://doi.org/10.1016/j.gloenvcha.2010.02.003.

- Schwartz, S.H., 2005. Robustness and fruitfulness of a theory of universals in individual values. Valores e trabalho.

- Schwartz, S.H., 2012. An overview of the Schwartz theory of basic values. Online Readings in Psychology and Culture, 2 (1), 11.

- Schwartz, S.H., Melech, G., Lehmann, A., Burgess, S., Harris, M., and Owens, V., 2001. Extending the cross-cultural validity of the theory of basic human values with a different method of measurement. Journal of cross-cultural psychology, 32 (5), 519-542, https://doi.org/10.1177\%2F0022022101032005001.

- Shum, R.Y., 2009. Can attitudes predict outcomes? Public opinion, democratic institutions and environmental policy. Environmental Policy and Governance, 19 (5), 281-295, https://doi.org/10.1002/eet.518.

- Sibley, C.G. and Kurz, T., 2013. A model of climate belief profiles: How much does it matter if people question human causation? Analyses of Social Issues and Public Policy, 13 (1), 245-261, https://doi.org/10.1111/asap.12008.

- Tjernström, E. and Tietenberg, T., 2008. Do differences in attitudes explain differences in national climate change policies? Ecological Economics, 65 (2), 315-324, https://doi.org/10.1016/j.ecolecon.2007.06.019.

- TNS Aisa., 2011. Co si Češi myslí o aktuálním dění v Národním parku Šumava? (výzkumná zpráva). Retrieved from http://simar.cz/clanky/co-si-cesi-mysli-o-aktualnim-deni-v-narodnim-parku-sumava.html

- TNS Aisa., 2012. Co si Češi myslí o aktuálním dění v Národním parku Šumava? (výzkumná zpráva). Retrieved from http://www.tns-aisa.cz/archived/54685

- Tranter, B., 2011. Political divisions over climate change and environmental issues in Australia. Environmental Politics, 20 (1), 78-96, https://doi.org/10.1080/09644016.2011.538167.

- Tranter, B., 2014. Social and political influences on environmentalism in Australia. Journal of Sociology, 50 (3), 331-348, https://doi.org/10.1177\%2F1440783312459102.

- Tranter, B. and Booth, K., 2015. Scepticism in a changing climate: a cross-national study. Global Environmental Change, 33, 154-164, https://doi.org/10.1016/j.gloenvcha.2015.05.003.

- Van den Berg, A.E. and Koole, S.L., 2006. New wilderness in the Netherlands: An investigation of visual preferences for nature development landscapes. Landscape and Urban Planning, 78, 362-372, https://doi.org/10.1016/j.landurbplan.2005.11.006.

- Vidomus, P., 2013. Climate Scepticism in the Czech Republic: An Introduction. Sociální studia, 95-127. 
- Waller, M., 2010. The environmental issue in the East of Europe: top-down, bottom-up and outside-in. Environmental Politics, 19 (5), 831-849, https://doi.org/10.1080/09644016.2010.508315.

- Weaver, A.A., 2008. Does Protest Behavior Mediate the Effects of Public Opinion on National Environmental Policies? A Simple Question and a Complex Answer. International Journal of Sociology, 38 (3), 108-125, https://doi.org/10.2753/IJS00207659380305.

- Whitmarsh, L., 2011. Scepticism and uncertainty about climate change: Dimensions, determinants and change over time. Global Environmental Change, 21 (2), 690-700, https://doi.org/10.1016/j.gloenvcha.2011.01.016. 


\section{Appendices}

\section{Appendix A: A representative sample for the Czech Republic}

\begin{tabular}{|c|c|c|}
\hline & $\begin{array}{l}\text { Representation in } \\
\text { the Study }\end{array}$ & $\begin{array}{l}\text { Representation in the } \\
\text { Czech Republic }\end{array}$ \\
\hline \multicolumn{3}{|l|}{ Gender } \\
\hline Male & $48.5 \%$ & $48.4 \%$ \\
\hline Female & $51.5 \%$ & $51.6 \%$ \\
\hline \multicolumn{3}{|l|}{ Age } \\
\hline $18-24$ years & $10.9 \%$ & $10.8 \%$ \\
\hline $25-34$ years & $18.2 \%$ & $18.5 \%$ \\
\hline $35-44$ years & $18.3 \%$ & $18.5 \%$ \\
\hline $45-54$ years & $16.2 \%$ & $15.8 \%$ \\
\hline $55-64$ years & $17.4 \%$ & $17.4 \%$ \\
\hline 65 years + & $19,00 \%$ & $19.2 \%$ \\
\hline \multicolumn{3}{|l|}{ Education } \\
\hline Primary & $16.2 \%$ & $16.3 \%$ \\
\hline $\begin{array}{l}\text { Secondary (not concluded by the national } \\
\text { school-leaving exam) }\end{array}$ & $35.4 \%$ & $36,00 \%$ \\
\hline $\begin{array}{l}\text { Secondary (concluded by the national } \\
\text { school-leaving exam) }\end{array}$ & $33.9 \%$ & $34.1 \%$ \\
\hline University & $14.4 \%$ & $13.6 \%$ \\
\hline \multicolumn{3}{|l|}{ Place of domicile size } \\
\hline up to 999 inhabitants & $14.6 \%$ & $17.1 \%$ \\
\hline $1,000-4,999$ inhabitants & $22.7 \%$ & $21.4 \%$ \\
\hline $5,000-19,999$ inhabitants & $18.5 \%$ & $18.1 \%$ \\
\hline $20,000-99,999$ inhabitants & $21.6 \%$ & $21.2 \%$ \\
\hline $100,000+$ inhabitants & $10.6 \%$ & $10.4 \%$ \\
\hline Prague & $12,0 \%$ & $11.9 \%$ \\
\hline
\end{tabular}


Appendix B: Description of the variables

\begin{tabular}{|c|c|c|c|c|c|c|}
\hline & & Mean & SD & Min & Max & $\begin{array}{l}\text { Cronbach } \\
\text { Alpha }\end{array}$ \\
\hline \multicolumn{7}{|c|}{ INDEPENDENT VARIABLES } \\
\hline Gender & [1=male; 2=female $]$ & 1.51 & 0.50 & 1.00 & 2.00 & \\
\hline Age & How old are you? & 46.40 & 16.83 & 18.00 & 88.00 & \\
\hline Education & $\begin{array}{l}\text { What is your level of completed education? [ } 1=\text { primary; } 2=\text { secondary not } \\
\text { concluded by the national school-leaving exam, trade school; } 3=\text { secondary } \\
\text { concluded by the national school-leaving exam; } 4=\text { higher specialization, Ba- } \\
\text { chelor's Degree; } 5=\text { higher specialization, Master's Degree, Doctorate or } \\
\text { higher] }\end{array}$ & 2.56 & 1.11 & 1.00 & 5.00 & \\
\hline $\begin{array}{l}\text { Net monthly per } \\
\text { capita household } \\
\text { income }\end{array}$ & $\begin{array}{l}\text { What is currently the net monthly income of your household? A rough figure } \\
\text { is sufficient. [1=less than } 10,000 \mathrm{CZK}, 2=10,001-15,000 \mathrm{CZK} ; 3=15,001- \\
20,000 \mathrm{CZK} ; 4=20,001-25,000 \mathrm{CZK} ; 5=25,001-30,000 \mathrm{CZK} ; 6=30,001- \\
45,000 \mathrm{CZK} ; 7=45,001-55,000 \mathrm{CZK} ; 8=55,001-65,000 ; 9=65,001- \\
75,000 \mathrm{CZK} ; 10=75,001-85,000 \mathrm{CZK} ; 11=85,001-95,000 \mathrm{CZK} ; \\
12=95,001 \mathrm{CZK} \text { and higher] To determine the range, we used the average } \\
\text { value which we divided by the number given in the response to the question: } \\
\text { How many people live in your household during most of the week? Please re- } \\
\text { member to include yourself (and if applicable, also your children). }\end{array}$ & 13052.67 & 6946.88 & 0.00 & 60000.00 & \\
\hline $\begin{array}{l}\text { Place of domicile } \\
\text { size }\end{array}$ & $\begin{array}{l}\text { What is the size of the municipality you currently live in (for most of the } \\
\text { week)? }[1=\text { up to } 999 \text { people; } 2=1,000-4,999 \text { people; } 3=5,000-19,999 \\
\text { people; } 4=20,000-49,999 \text { people; } 5=50,000-99,999 \text { people; } 6=100,000 \\
-999,999 \text { people; } 7=1,000,000 \text { or more people / Prague ] }\end{array}$ & 3.60 & 1.96 & 1.00 & 7.00 & \\
\hline $\begin{array}{l}\text { Election partici- } \\
\text { pation }\end{array}$ & $\begin{array}{l}\text { Have you cast your vote in the following elections....? [battery average; } \\
1=\text { yes; } 0=\text { no; missing=not sure] a) local election (October 2014); b) Euro- } \\
\text { pean Parliament election (May 2014); c) Parliament Lower House election } \\
\text { (October 2013); presidential election (January 2013, at least one of the two } \\
\text { rounds) }\end{array}$ & 0.55 & 0.41 & 0.00 & 1.00 & 0.867 \\
\hline
\end{tabular}




\begin{tabular}{|c|c|c|c|c|c|c|}
\hline & & Mean & SD & Min & Max & $\begin{array}{l}\text { Cronbach } \\
\text { Alpha }\end{array}$ \\
\hline Left-right scale & $\begin{array}{l}\text { If the Parliamentary elections were taking place next week, which political } \\
\text { party would you vote for? [choice from a list of Czech political parties] } \\
\text { [coded } 1=\text { =left-wing political subject; } 2=\text { =entre-of-scale political subject; } \\
3=\text { right-wing political subject; missing=don't want to vote / don't know] }\end{array}$ & 2.02 & 0.62 & 1 & 3 & \\
\hline $\begin{array}{l}\text { Liberal-conser- } \\
\text { vative scale }\end{array}$ & $\begin{array}{l}\text { If the Parliamentary elections were taking place next week, which political } \\
\text { party would you vote for? [choice from a list of Czech political parties] } \\
\text { [coded } 1=\text { liberal political subject; } 2=\text { centre-of-scale political subject; } 3=\text { con- } \\
\text { servative political subject; missing=don't want to vote / don't know] }\end{array}$ & 1.81 & 0.74 & 1 & 3 & \\
\hline $\begin{array}{l}\text { Trust in scientific } \\
\text { and research in- } \\
\text { stitutions }\end{array}$ & $\begin{array}{l}\text { For each of the following institutions, please mark how strongly you perso- } \\
\text { nally trust it. [0=I don't trust it at all, } 10=\text { I trust it completely] scientific and } \\
\text { research institutions }\end{array}$ & 6.59 & 2.42 & 0.00 & 10.00 & \\
\hline $\begin{array}{l}\text { Trust in non-pro- } \\
\text { fit organizations }\end{array}$ & $\begin{array}{l}\text { For each of the following institutions, please mark how strongly you perso- } \\
\text { nally trust it. [0=I don't trust it at all, } 10=\text { I trust it completely] non-profit or- } \\
\text { ganizations }\end{array}$ & 5.60 & 2.52 & 0.00 & 10.00 & \\
\hline $\begin{array}{l}\text { Factor of secu- } \\
\text { rity }\end{array}$ & [Portrait Values Questionnaire, 21 items, result of factor analysis] & 0.00 & 1.00 & -4.89 & 3.01 & \\
\hline $\begin{array}{l}\text { Factor of ego- } \\
\text { motivation }\end{array}$ & [Portrait Values Questionnaire, 21 items, result of factor analysis] & 0.00 & 1.00 & -3.27 & 2.57 & \\
\hline $\begin{array}{l}\text { Factor of al- } \\
\text { truism }\end{array}$ & [Portrait Values Questionnaire, 21 items, result of factor analysis] & 0.00 & 1.00 & -4.00 & 3.00 & \\
\hline $\begin{array}{l}\text { Factor of confor- } \\
\text { mity }\end{array}$ & [Portrait Values Questionnaire, 21 items, result of factor analysis] & 0.00 & 1.00 & -4.52 & 3.43 & \\
\hline $\begin{array}{l}\text { Leisure-time in } \\
\text { nature }\end{array}$ & $\begin{array}{l}\text { In the statements that follow, "nature" refers to areas you know, have visi- } \\
\text { ted or spent some time in, whether regularly or occasionally, e.g. natural } \\
\text { preserves, woods, rivers, mountains, mountain areas, rural areas. Up to } \\
\text { what extent do you agree or disagree with the following statements? } \\
\text { [average value; } 7=\text { totally agree to } 1=\text { totally disagree; following Reser et al. } \\
\text { (2012, p. } 251 \text { ) - selected items concerning leisure time voluntarily spent in } \\
\text { nature] a) I frequently engage in activities that are located in natural envi- }\end{array}$ & 4.2034 & 1.60655 & 1.00 & 7.00 & 0.773 \\
\hline
\end{tabular}




\begin{tabular}{|c|c|c|c|c|c|c|}
\hline & & Mean & SD & Min & Max & $\begin{array}{l}\text { Cronbach } \\
\text { Alpha }\end{array}$ \\
\hline & $\begin{array}{l}\text { ronment. b) I often spend time with family and friends relaxing in the natu- } \\
\text { ral environment. c) I prefer to spend my time in the country rather than the } \\
\text { town/city. }\end{array}$ & & & & & \\
\hline $\begin{array}{l}\text { New Ecological } \\
\text { Paradigm }\end{array}$ & [New Ecological Paradigm Scale (Dunlap et al. 2000); battery average] & 3.45 & 0.52 & 1.53 & 4.93 & 0.802 \\
\hline \multicolumn{7}{|c|}{ DEPENDENT VARIABLES - CLIMATE PROTECTION } \\
\hline $\begin{array}{l}\text { Consent with cli- } \\
\text { mate protection }\end{array}$ & $\begin{array}{l}\text { Up to what extent do you agree or disagree with the statement that we know } \\
\text { about climate change enough to justify that the issue requires action? } \\
\text { [following Ashworth et al. ( } 2011) ; 1=\text { definitely disagree; } 2=\text { rather disagree; } \\
3=\text { not sure, don't know; } 4=\text { rather agree; } 5=\text { definitely agree] }\end{array}$ & 2.86 & 1.52 & 1.00 & 5.00 & \\
\hline $\begin{array}{l}\text { Concern for cli- } \\
\text { mate change }\end{array}$ & $\begin{array}{l}\text { How much harm do you think global climate change is going make to ... } \\
\text { [following Ashworth et al. (2011, p.21) supplemented with other items; } \\
1=\text { not at all; } 2=\text { little; } 3=\text { medium; } 4=\text { a lot] a) the world as a whole; b) you } \\
\text { as a person; c) people around the world; d) nature - excluding people; e) } \\
\text { the area you live in; f) future generations; g) the Czech Republic. }\end{array}$ & 2.36 & 1.04 & 1.00 & 4.00 & 0.975 \\
\hline $\begin{array}{l}\text { Conviction about } \\
\text { political respon- } \\
\text { sibility for cli- } \\
\text { mate protection }\end{array}$ & $\begin{array}{l}\text { Who do you believe should be responsible for activities to counteract the glo- } \\
\text { bal climate change? [following Reser et al. (2012) with supplementary scale; } \\
\text { battery average; } 0=\text { not at all; } 1=\text { =little; } 2=\text { medium; } 3=\text { a lot] a) individuals } \\
\text { and their families; b) industry / businesses; c) local authorities, d) Czech } \\
\text { government; e) international community; f) European Union; g) environ- } \\
\text { mental associations }\end{array}$ & 1.71 & 1.18 & 0.00 & 3.00 & 0.974 \\
\hline
\end{tabular}




\begin{tabular}{|c|c|c|c|c|c|c|}
\hline & & Mean & SD & Min & Max & $\begin{array}{l}\text { Cronbach } \\
\text { Alpha }\end{array}$ \\
\hline $\begin{array}{l}\text { Personal invol- } \\
\text { vement in cli- } \\
\text { mate protection }\end{array}$ & $\begin{array}{l}\text { In the past year, did you do any of the climate protection activities listed } \\
\text { here? [battery average; } 0=\text { not at all; } 1=\text { partly yes; } 2=\text { definitely yes] The } \\
\text { factor analysis is based on these items: a) Did you participate in any volun- } \\
\text { teer activities in support of climate protection, e.g. by organizing something, } \\
\text { by doing manual work, administrative work, scientific work, teaching etc.? b) } \\
\text { Did you sign a petition in support of climate protection? c) Did you express } \\
\text { your personal opinion in support of climate protection, e.g. in face to face } \\
\text { meetings, on the internet, in some other way? d) Did you become a member } \\
\text { of an organization that supports climate protection? e) Did you donate } \\
\text { money or goods in support of climate protection? f) Did you write to public } \\
\text { offices, to politicians or to companies in support of climate protection? g) } \\
\text { When shopping, did you give preference to goods that contribute to climate } \\
\text { change as little as possible? h) Did you wear a t-shirt, a badge or a sticker in } \\
\text { support of climate protection? i) Did you lower the consumption of energy or } \\
\text { water in your household to support climate protection? j) Did you give prefe- } \\
\text { rence to modes of transportation that contribute to climate change as little } \\
\text { as possible, that is, did you limit car driving and flying? }\end{array}$ & 0.22 & 0.32 & 0.00 & 2.00 & 0.859 \\
\hline $\begin{array}{l}\text { Overall support } \\
\text { to climate pro- } \\
\text { tection }\end{array}$ & $\begin{array}{l}\text { Factor obtained by factor analysis of the following scales: Concern about cli- } \\
\text { mate change; Conviction of political responsibility for climate protection; and } \\
\text { Personal involvement in climate protection (see Table } 3 \text { ). }\end{array}$ & 0.00 & 1.00 & -1.36 & 2.88 & \\
\hline \multicolumn{7}{|c|}{ DEPENDENT VARIABLES - WILDLIFE PROTECTION } \\
\hline $\begin{array}{l}\text { Consent with } \\
\text { wildlife pro- } \\
\text { tection }\end{array}$ & $\begin{array}{l}\text { Do you believe wildlife in the Czech Republic needs protection? [1=definitely } \\
\text { not; } 2=\text { rather not; } 3=\text { not sure, don't know; } 4=\text { rather yes; } 5=\text { definitely yes] }\end{array}$ & 3.93 & 1.012 & 1.00 & 5.00 & \\
\hline $\begin{array}{l}\text { Concern for } \\
\text { wildlife }\end{array}$ & $\begin{array}{l}\text { Up to what extent do you think the following factors pose a long-term threat } \\
\text { to wildlife protection? [following McFarlane, 2005; battery average; } 1=\text { not a } \\
\text { threat to } 5=\text { big threat] a) Insects or diseases dangerous to plants and ani- } \\
\text { mals; b) The mass of woods being lumbered; c) Deforestation due to urbani- } \\
\text { sation (e.g. to acquire new housing areas); d) Climate change or global war- } \\
\text { ming; d) Loss of old, mature trees; e) Lumbering methods; f) Deforestation } \\
\text { due to agriculture; g) Oil and natural gas surveys and piping; h) Amount of }\end{array}$ & 3.47 & 0.65 & 1.00 & 5.00 & 0.883 \\
\hline
\end{tabular}




\begin{tabular}{|c|c|c|c|c|c|c|}
\hline & & Mean & SD & Min & Max & $\begin{array}{l}\text { Cronbach } \\
\text { Alpha }\end{array}$ \\
\hline & $\begin{array}{l}\text { forest land in lumbering areas; i) Lumbering; j) Forest fires; k) Genetic mo- } \\
\text { difications of tree species; I) Massive hunting; m) Pastures in forest areas; } \\
\text { n) Massive scale of recreational activities in woodland. }\end{array}$ & & & & & \\
\hline $\begin{array}{l}\text { Conviction-about } \\
\text { political respon- } \\
\text { sibility for } \\
\text { wildlife pro- } \\
\text { tection }\end{array}$ & $\begin{array}{l}\text { Who should, according to you, be held responsible for wildlife protection? } \\
\text { [following Reser et al. (2012) with supplementary scale; battery average; } \\
0=\text { not at all; } 1=\text { little; } 2=\text { medium; } 3=\text { a lot] a) individuals and their families; } \\
\text { b) industry / businesses; c) local authorities; d) Czech government; e) the } \\
\text { international community; f) European Union; g) environmental associations. }\end{array}$ & 2.25 & 0.61 & 0.00 & 3.00 & 0.831 \\
\hline $\begin{array}{l}\text { Personal invol- } \\
\text { vement in } \\
\text { wildlife pro- } \\
\text { tection }\end{array}$ & $\begin{array}{l}\text { Were you involved in some of the following wildlife protection activities in the } \\
\text { past year? [battery average; } 0=\text { not at all; } 1 \text { =partly yes; } 2 \text { =definitely yes] } \\
\text { a) Were you involved in voluntary work contributing to wildlife protection, } \\
\text { e.g. by organizing, manual work, legislation, expert work, educational work } \\
\text { etc.?; b) Have you signed a wildlife protection petition?; c) Have you expres- } \\
\text { sed your opinion in support of wildlife protection, e.g. in face-to-face en- } \\
\text { counters, on the internet or otherwise?; d) Have you become a member of a } \\
\text { wildlife protection organization?; e) Have you supported wildlife protection } \\
\text { financially or in other material ways?; f) Have you written to authorities, po- } \\
\text { liticians or businesses regarding wildlife protection?; g) When shopping, do } \\
\text { you prefer products not harming wildlife?; h) Have you worn a T-shirt, a } \\
\text { badge or a sticker in support of wildlife protection?; i) In wildlife areas, have } \\
\text { you only used services not harming nature - have you avoided using ski lifts, } \\
\text { four-wheelers etc.?; j) Have you left places for wild animals and plants in } \\
\text { plots of land in your care (for hedgehogs, beetles etc.)? }\end{array}$ & 0.18 & 0.29 & 0.00 & 2.00 & 0.813 \\
\hline $\begin{array}{l}\text { Overall support } \\
\text { to wildlife pro- } \\
\text { tection }\end{array}$ & $\begin{array}{l}\text { Factor obtained by factor analysis of the following scales: Concern about } \\
\text { wildlife protection; Conviction about political responsibility for wildlife pro- } \\
\text { tection; and Personal Involvement in wildlife protection (see Table 4). }\end{array}$ & 0.00 & 1.00 & -3.34 & 3.55 & \\
\hline
\end{tabular}

